IRA-International Journal of Applied Sciences

ISSN 2455-4499; Vol.03, Issue 03 (2016)

Institute of Research Advances

http://research-advances.org/index.php/IRAJAS

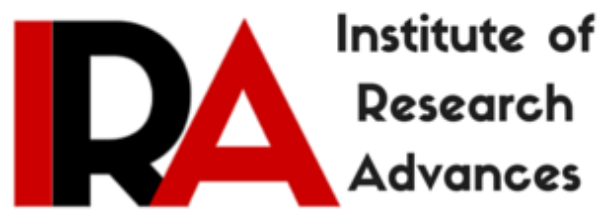

\title{
A Study to Assess and Compare the Effectiveness of Moist Heat Versus Ice Packs Application in Reducing the Signs and Symptoms of Intravenous Cannulation Induced Thrombophlebitis Among Patients Admitted in Civil Hospital of Dausa District, Rajasthan
}

\author{
${ }^{1}$ Vijay Kumar Gauttam \\ PhD Scholar, MJRP University, Jaipur, India. \\ ${ }^{2}$ Dr. Jogindra Vati \\ Professor (PhD Guide), MJRP University, Jaipur, India.
}

DOI: http://dx.doi.org/10.21013/jas.v3.n3.p11

\section{How to cite this paper:}

Gauttam, V., \& Vati, D. (2016). A Study to Assess and Compare the Effectiveness of Moist Heat Versus Ice Packs Application in Reducing the Signs and Symptoms of Intravenous Cannulation Induced Thrombophlebitis Among Patients Admitted in Civil Hospital of Dausa District, Rajasthan. IRA-International Journal of Applied Sciences (ISSN 2455-4499), 3(3). doi:http://dx.doi.org/10.21013/jas.v3.n3.p11

(C) Institute of Research Advances

\section{(c)) EY-NC}

This works is licensed under a Creative Commons Attribution-Non Commercial 4.0 International License subject to proper citation to the publication source of the work.

Disclaimer: The scholarly papers as reviewed and published by the Institute of Research Advances (IRA) are the views and opinions of their respective authors and are not the views or opinions of the IRA. The IRA disclaims of any harm or loss caused due to the published content to any party. 


\begin{abstract}
Peripheral Intravenous (I.V.) cannulation is an invasive procedure which predisposes the patient to an increased risk of local and systemic infection from micro-organisms introduced either at the time of insertion or when in situ. Peripheral I.V. cannulae related infections are associated with increased morbidity, prolonged hospitalization and increased costs. Therefore, a study to assess and compare the effectiveness of moist heat versus ice packs application in reducing the signs and symptoms of intravenous cannulation induced thrombophlebitis among patients. A pre experimental research approach using one group pre-test post-test repeated measure design was used to assess and compare the effectiveness of moist heat versus ice packs application in reducing the signs and symptoms of intravenous cannulation induced thrombophlebitis. The study was conducted in medical and surgical wards of the Civil Hospital, Dausa district and a sample of 60 (30 patients in each group) was selected using purposive sampling technique. Treatment with moist heat and ice packs application for 20 minutes every two hourly were given to both the group. Modified visual infusion phlebitis was used to assess the prevalence of sign and symptoms of I.V. cannulation thrombophlebitis and Numerical Rating Scale was used for pain assessment. The obtained data was analyzed using both descriptive and inferential statistics in terms of frequencies, percentages and chi square association. The moist heat and ice packs were equally effective in reducing the signs and symptoms of I.V. cannulation induced thrombophlebitis i.e. pain, Erythema, induration and warmth. The moist heat was sustained, but ice packs had immediate effects in reducing the signs and symptoms of I.V. cannulation induced thrombophlebitis. There were no association between the level of pain, Erythema, induration and warmth with selected personal variables.
\end{abstract}

Key words: Intravenous Cannulation, Thrombophlebitis, Moist heat, Ice Packs, signs and symptoms.

\title{
BACKGROUND
}

Peripheral Intravenous (I.V.) cannulation is an invasive procedure which predisposes the patient to an increased risk of local and systemic infection from micro-organisms introduced either at the time of insertion or when in situ. Peripheral I.V. cannulae related infections are associated with increased morbidity, prolonged hospitalization and increased costs. Infections are most commonly caused by Staphylococci. The predominant source of these micro-organisms is likely to be from the patient's endogenous flora colonizing the skin or from the hands of the health care practitioner ${ }^{1}$.

The risk of phlebitis exceeds to 50\% after the fourth day of cannula placement and the major contributing factors of phlebitis are intravenous antibiotics, female gender and catheterization for longer than 48 hours and catheter material. There was a twofold lower rate of infusion-related phlebitis and reduction of catheter-related sepsis occurred when experienced nurses on an intravenous therapy team inserted intravenous catheters and provide close surveillance of infusion sites ${ }^{2}$.

\section{Need for the Study and Literature Review}

Peripheral intravenous cannulation is one of the most common invasive procedure that nurse perform and it carries high risk of complications like phlebitis $80 \%$ and other complications include thrombophlebitis, infection resulting from bacteremia and septicemia ${ }^{3}$. 
A comparative study was conducted in Pune on effectiveness of hot fomentation versus cold compress for reducing intravenous infiltration. The sample size was sixty patients (30 for hot fomentation and 30 for cold compress) with mild to moderate degree of infiltration stayed in hospital for 8-14 days and data was analysed by using descriptive and inferential statistics. Findings prove that the pre-treatment mean score of degree of infiltration was 7.1667 reduced to 0.7071 on the third day of treatment with hot fomentation. In cold compress pre-treatment mean score 6.9333 reduced to 0.70571 . The study concluded that both hot fomentation and cold compress are effective in treatment of intravenous therapy related infiltration ${ }^{4}$.

\section{OBJECTIVES}

- To assess and compare the effectiveness of moist heat and ice packs in reducing the signs and symptoms of intravenous (I.V.) cannulation induced thrombophlebitis among the patients.

\section{HYPOTHESES}

- $\mathbf{H}_{\mathbf{1}^{-}}$There will be a significant reduction in signs and symptoms of intravenous cannulation induced thrombophlebitis among the patients after the moist heat application.

- $\mathbf{H}_{2^{-}}$There will be a significant reduction in signs and symptoms of intravenous cannulation induced thrombophlebitis among the patients after the ice packs application.

- $\mathbf{H}_{3^{-}}$There will be a significant difference in the effectiveness of moist heat and ice packs in reducing the signs and symptoms of intravenous cannulation induced thrombophlebitis among the patients.

\section{CONCEPTUAL FRAME WORK}

Conceptual framework deals with "abstraction that is assembled by virtue of relevance to s common phenomenon". Conceptual framework is a group of mental image or concepts that are related to, but relationship is not explicit.

The purpose of conceptual framework is to provide a logical, coherent structure through which phenomena of concern can be understood and discussed. It provides broad perspectives for nursing practices, research and education. Conceptual framework plays several interrelated roles in the progress of science. Their overall purposes are to make scientific feedings meaningful and generalizable.

According to Polit and Hungler (1999) "Conceptual frameworks represents a less formal and less well developed attempt at organization phenomena than theory and deal with abstractions that are assemble by virtue of their relevance the common theme.

The Conceptual framework adopted for the present study is based on the general system model given by Von Bertanffy. The model is characterized by input, process and output.

(Figure-1). 


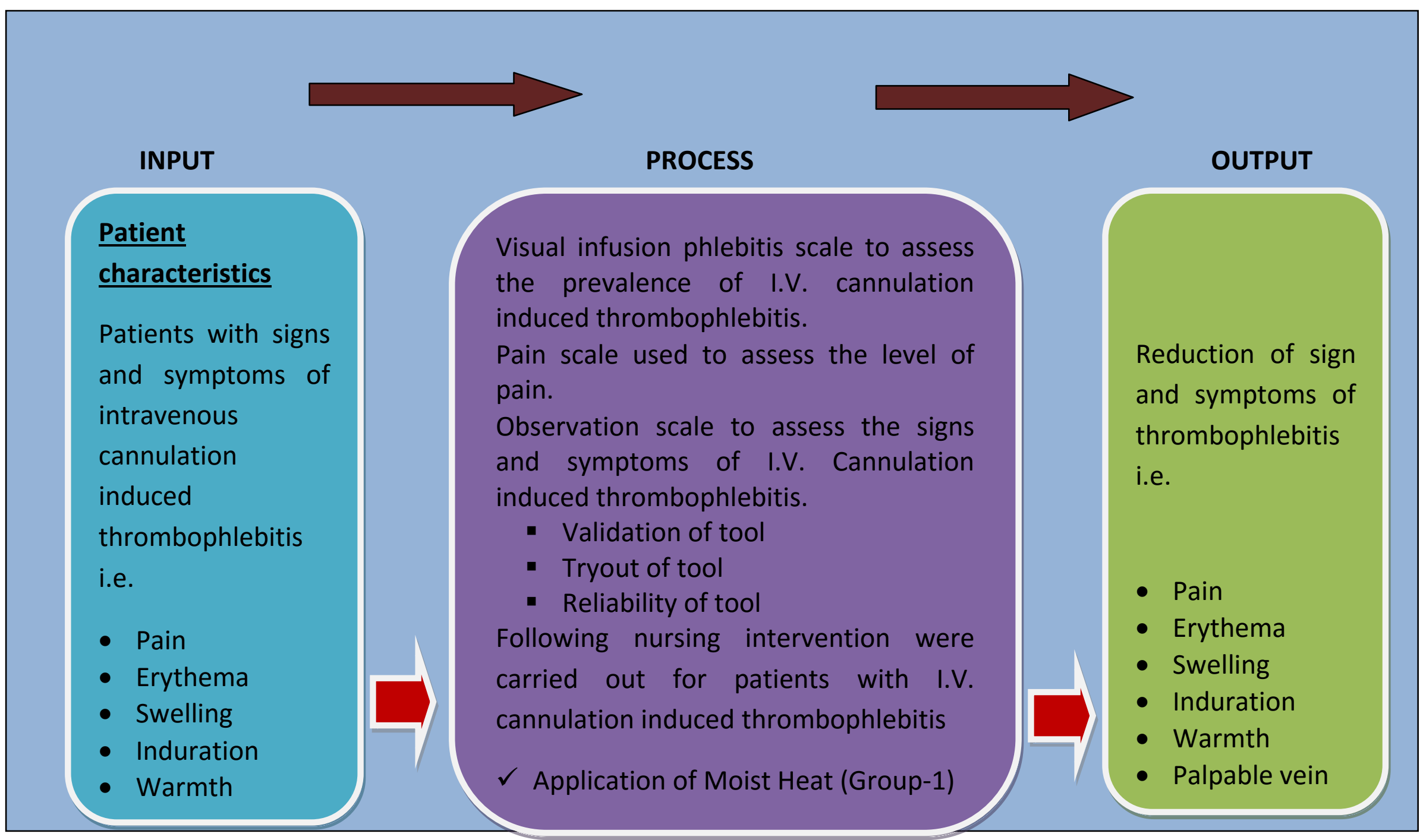

Figure: 1 Modified Conceptual Framework Based on System Approach 


\section{METHODOLOGY}

Research Approach: Pre Experimental Researh Approach was adopted in this study.

Research design: One group pre-test post-test repeated measure design was used.

Population: The population consisted of Patients admitted in Male/female medical and surgical ward of Civil Hospital, Dausa district.

Sample and Sample size: The sample consists of 60 patients (30 in moist heat application and 30 in ice packs application group) having intravenous cannulation induced thrombophlebitis.

Sampling Technique: The sampling technique used in this study was Purposive sampling technique.

Setting of the study: The study was conducted in Civil Hospital, Dausa District (Rajasthan)

Description of the tools: The tool constructed in this study was divided in to four sections:

\section{Section-1: Performa for Personal Variables}

- Age

- Gender

- Marital status

- Education status

- Types of family

- Religion

- Occupation

- Total family income

Precipitating factors for I.V. cannulation induced thrombophlebitis.

- Size of I.V. cannula

- Site of I.V. cannulation

- Duration of I.V. cannula in situ.

- Types of I.V. fluid administered

- Intravenous infusion administered.

- Rate of I.V. infusion.

Section-2: The modified visual infusion phlebitis scale to assess prevalence of the sign and symptoms of I.V. cannulation induced thrombophlebitis.

It is standardized tool developed by Nancy Ashton. It was modified as suggested by the experts. It consists of 0 to 4 grades according to signs and symptoms.

Grade-0: No sign of phlebitis was present around the I.V. cannulation site.

Grade-1: Pain or erythema is present.

Grade-2: Two signs and symptoms were present i.e. pain, erythema.

Grade-3: More than two sign and symptoms were present pain, erythema, warmth and induration. 
Grade-4: pain, erythema, warmth, induration and palpable vein.

\section{Section-3: Observation scale for sign and symptoms of I.V. cannulation induced thrombophlebitis.}

Scoring of pain, erythema, induration and warmth was done according to the severity i.e. no sign and symptoms, mild, moderate and severe.

Score zero (0) was given for absence of erythema, swelling, warmth, induration and palpable vein.

Mild (1): Erythema $\leq 1$ or $15 \mathrm{~cm}^{2}$, induration $\leq 1$ or $10 \mathrm{~cm}^{2}$, sewlling $\leq 1$ or $1 \mathrm{~cm}^{2}$, palpable vein $\leq 1$ or 1 inch.

Moderate (2): Erythema 16-30 $\mathrm{cm}^{2}$, induration $11-20 \mathrm{~cm}^{2}$, sewlling $11-20 \mathrm{~cm}^{2}$, palpable vein 2-3 inch.

Severe (3): Erythema $\square 30 \mathrm{~cm}^{2}$, induration $\square 20 \mathrm{~cm}^{2}$, sewlling $\square 20 \mathrm{~cm}^{2}$, palpable vein $\square 3$ inch.

\section{Section-4: Numerical Rating Scale (Mc Caffery \& Pasero 1999) was used for pain assessment.}

The Numerical Rating Scale (NRS) ('0-10' point pain intensity scale) developed by Mc Caffery \& Pasero 1999 was used to measure the intensity of pain before and after application of moist heat and ice packs. Patient's expressed their intensity of pain from 0-10 numbers on numerical rating pain scale. The intensity of pain scored as follows:

No pain (0): 0, Mild pain (1): 1-3, Moderate pain (2): 4-6, Severe pain (3): 7-10

Validity: The tool was given to seven experts, which included three from nursing experts, two from medical experts and two from physiotherapist.

Reliability: The reliability coefficients of the tool were found using inter rater reliability by Kappa method was found to be 0.74 for pain scale, 0.76 for induration, 0.74 for warmth, 0.75 for erythema. The Kappa method of inter rater reliability for ice packs application was found to be 0.71 for pain, 0.73 for induration, 0.70 for warmth and 0.74 for erythema. The range of acceptability by Kappa is from 0.60 to 1. The tools were found to be reliable for the purpose of the study.

\section{Pilot study}

Pilot study was conducted from 05.05.2015 to 10.05.2015 at Civil Hospital, Dausa district after obtaining permission from the administrative authorities i.e. CMO, Civil Hospital, Dausa district. Consent was taken those patients who were willing to participate in the study. After selection of the subjects were informed and assured them for confidentiality. Patients with intravenous cannulation induced thrombophlebitis were selected by purposive sampling technique from male/female medical and surgical wards. Treatment of moist heat application to group- 1 and ice packs application group-2 were given to the patients with I.V. cannulation induced thrombophlebitis. Total ten patients were taken five in each group. Numerical Rating Scale was used to assess intensity of pain and Observation scale was used to assess the severity of sign and symptoms of thrombophlebitis. After the statistical analysis, finding of the pilot study revealed that it will be feasible and criterion measures were found to be effective for conduct the final study. 


\section{Data collection process}

Final study was conducted at Civil Hospital, Dausa district in the month of 01.07.2015 to 25.07.2015 Formal administrative approval was obtained from CMO, Civil Hospital, Dausa district to conduct the study in selected wards. The staffs of the respective wards were informed to ensure their cooperation during data collection. The purpose of the study was explained to patients for their cooperation. The consent to participate in the study was taken from the patients. The purposive sampling techniques were used to select the patients with intravenous cannulation induced thrombophlebitis. Treatment of moist heat application to group-1 and ice packs application group-2 were given to the patients with I.V. cannulation induced thrombophlebitis. Every day two to three patients having I.V. cannulation induced thrombophlebitis were selected for the application of most heat. Total 30 patients were completed with moist heat application (Group-1). Similarly after moist heat application the patients were selected for ice packs applications (Group-2). The duration and frequency of the treatment was 20 minutes for four times in a day. The treatment to one patient was given for two days. On day one, four applications of treatment were given and first two observations were taken. On day second, next four applications of treatment were given and third and fourth observations were taken. Sign and symptoms and intensity of pain were assessed before and after giving the treatment.

\section{FINDINGS}

\section{Section I: Distribution of sample based on Personal variables.}

The result showed that among about $11(36.7 \%)$ and nearly $10(46.7 \%)$ of the patients were in the age group of 44-56 years in group-1 (moist heat application) and group-2 (ice packs application) respectively. 17 (56.7\%) and $13(43.3 \%)$ were female and male in both group-1 (moist heat) and group-2 (ice packs). As per marital status 27 (90\%) got moist heat and $20(67.7 \%)$ who received ice packs were married. 17 $(56.7 \%)$ and $15(50 \%)$ in group-1 (moist heat) and group-2 (ice packs) application were illiterate. 18(60\%) in group-1 (moist heat) and 16 (53.3\%) in group-2 (ice packs) were belongs to Hindu religion followed by $26 \%$ in group-1 (moist heat) and group-2 (ice packs) who were belonged to Sikh religion. As per types of family 21 (70\%) in group-1 (moist heat) and 22 (73.3\%) in group-2 (ice packs) were belonged to nuclear family followed by $30 \%$ and $26.7 \%$ in the group- 1 (moist heat) and group2 (ice packs) were residing in joint family. According to size of cannula $12(40 \%)$ in group-1 (moist heat) and $8(26.7 \%)$ in group-2 (ice packs) had eighteen gauge cannula. $13(43.3 \%)$ in group-1 (moist heat) and 12 (40\%) in group-2 (ice packs) had intravenous cannulation site in cephalic vein followed by $11(36.7 \%)$ and $13(43.3 \%)$ who had I.V. cannulation site in basilica vein. As per duration of I.V. cannulation more than 72 hours patients were 14(46.7\%) and 16 (53.3) in group-1 (moist heat) and group-2 (ice packs) respectively. $20(66.7 \%)$ in the group-1 (moist heat) and 23 (76.7\%) in group-2 (ice packs) had received hypertonic fluid whereas only $1(3.33 \%)$ patients had received hypotonic fluid in group-2 (ice packs). The patients 25 (83.3\%) in group-1 (moist heat) and 27 (90\%) in group-2 (ice packs) were found intravenous infusion with antibiotics. As per rate of I.V. Infusion 21 (70\%) in group-1 (moist heat) and $20(66.7 \%)$ group-2 (ice packs) had received intravenous infusion at rate of more than $100 \mathrm{ml}$. 
Section II: Prevalence of Intravenous Cannulation Induced Thrombophlebitis.

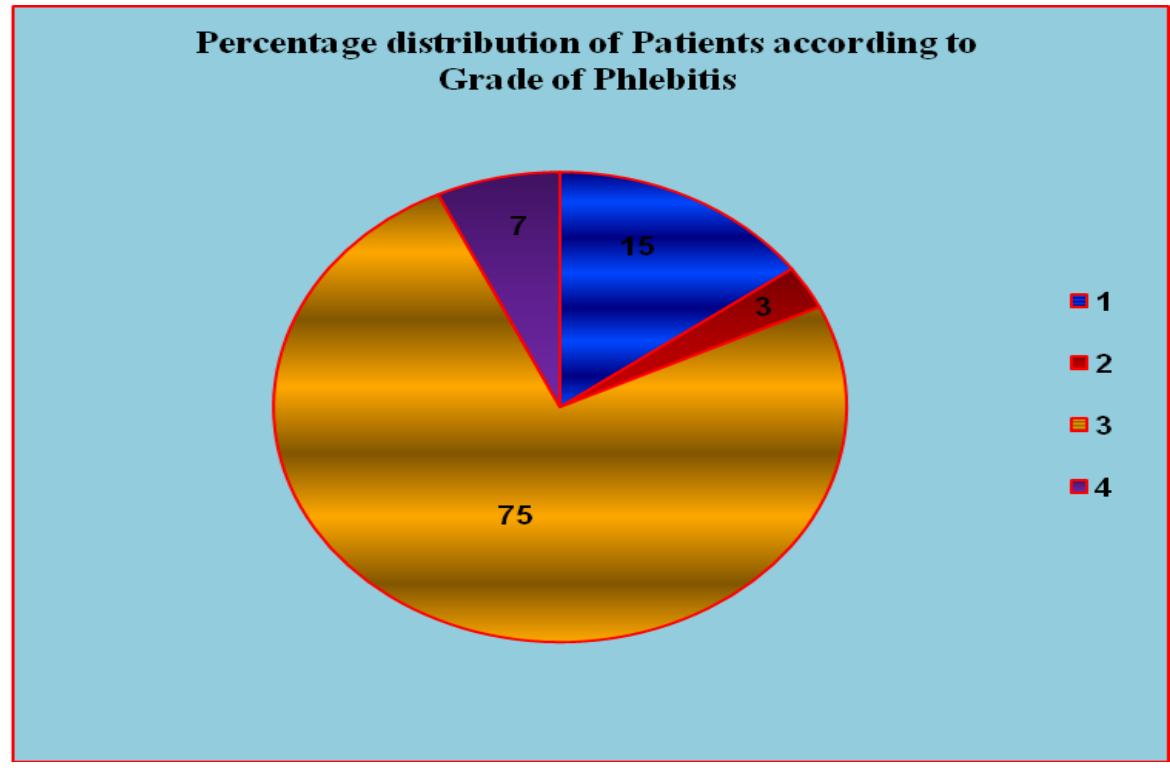

Figure: 2 Pie diagram showing the percentage distribution of patients as per their Grade of Phlebitis.

The above graph represents that maximum patient's i.e. $75 \%$ were in the Grade-3 of phlebitis and $9(15 \%), 2(3.33 \%), 4(6.66 \%)$ of patients had Grade 1, 2, 4 respectively.

Section III: comparison of pain, erythema, induration and warmth within the groups (group-1 and group-2).

Table-1: Comparison of severity of pain between pre test and post test observation score among group-1 (Moist Heat Application)

\begin{tabular}{|c|c|c|c|c|c|c|c|c|c|c|}
\hline \multirow{4}{*}{$\begin{array}{l}\text { Obser } \\
\text { vation }\end{array}$} & \multirow{2}{*}{\multicolumn{8}{|c|}{ Severity of Pain }} & \multirow{4}{*}{$\begin{array}{l}\text { Chi } \\
\text { Square } \\
\text { Vale }\end{array}$} & \multirow{4}{*}{$\begin{array}{r}=30 \\
\text { df }\end{array}$} \\
\hline & & & & & & & & & & \\
\hline & \multicolumn{2}{|c|}{ No Pain } & \multicolumn{2}{|c|}{ Mild } & \multicolumn{2}{|c|}{ Moderate } & \multicolumn{2}{|c|}{ Severe } & & \\
\hline & f & $\%$ & f & $\%$ & f & $\%$ & f & $\%$ & & \\
\hline $\mathbf{O}_{\mathrm{m} 1 \mathrm{~d} 1}$ & 00 & 0.0 & 03 & 10.0 & 10 & 33.3 & 17 & 56.6 & \multirow{2}{*}{$10.64 *$} & \multirow{2}{*}{3} \\
\hline$O_{\mathrm{m} 2 \mathrm{~d} 1}$ & 04 & 13.4 & 07 & 23.3 & 15 & 50.0 & 04 & 13.3 & & \\
\hline $\mathbf{O}_{\mathrm{m} 2 \mathrm{~d} 1}$ & 04 & 13.3 & 07 & 23.3 & 15 & 50.0 & 04 & 13.3 & \multirow{2}{*}{$3.81^{\mathrm{NS}}$} & \multirow{2}{*}{3} \\
\hline $\mathrm{O}_{\mathrm{m} 3 \mathrm{~d} 2}$ & 08 & 26.6 & 12 & 40.0 & 07 & 23.3 & 03 & 10.0 & & \\
\hline$O_{m 1 d 1}$ & 00 & 0.0 & 03 & 10.0 & 10 & 33.3 & 17 & 56.6 & \multirow{2}{*}{$19.07^{*}$} & \multirow{2}{*}{3} \\
\hline $\mathbf{O}_{\mathrm{m} 3 \mathrm{~d} 2}$ & 08 & 26.6 & 12 & 40.0 & 07 & 23.3 & 03 & 10.0 & & \\
\hline $\mathbf{O}_{\mathrm{m} 3 \mathrm{~d} 2}$ & 08 & 26.6 & 12 & 40.0 & 07 & 23.3 & 03 & 10.0 & \multirow{2}{*}{$6.50^{\mathrm{NS}}$} & \multirow{2}{*}{3} \\
\hline $\mathbf{O}_{\mathrm{m} 4 \mathrm{~d} 2}$ & 19 & 63.3 & 06 & 20.0 & 05 & 16.6 & 00 & 0.00 & & \\
\hline $\mathbf{O}_{\mathrm{m} 1 \mathrm{~d} 1}$ & 00 & 0.0 & 03 & 10.0 & 10 & 33.3 & 17 & 56.6 & \multirow{2}{*}{$33.62 *$} & \multirow{2}{*}{3} \\
\hline$O_{\mathrm{m} 4 \mathrm{~d} 2}$ & 19 & 63.3 & 06 & 20.0 & 07 & 23.3 & 04 & 13.3 & & \\
\hline
\end{tabular}

The above data showed that application of moist heat has significantly reduced the severity of pain as the computed chi square value between pre-test and post-test i.e. 
$\mathrm{O}_{\mathrm{m} 1 \mathrm{~d} 1} \mathrm{Vs} \mathrm{O}_{\mathrm{m} 2 \mathrm{~d} 2}(10.64 \mathrm{P}<0.05), \mathrm{O}_{\mathrm{m} 1 \mathrm{~d} 1} \mathrm{Vs} \mathrm{O}_{\mathrm{m} 3 \mathrm{~d} 2}(19.07 \mathrm{P}<0.05), \& \mathrm{O}_{\mathrm{m} 1 \mathrm{~d} 1} \mathrm{Vss}_{\mathrm{m}} \mathrm{O}_{\mathrm{m} 22}$ $(33.62 \mathrm{P}<0.05)$, were found to be significant at 0.05 level of significance.

Table-2: Comparison of severity of Erythema between pre test and post test observation score among group-1 (Moist Heat Application)

$\mathbf{n}=\mathbf{3 0}$

\begin{tabular}{|c|c|c|c|c|c|c|c|c|c|c|}
\hline \multirow{3}{*}{$\begin{array}{l}\text { Obser } \\
\text { vation }\end{array}$} & \multicolumn{8}{|c|}{ Erythema } & \multirow{3}{*}{$\begin{array}{l}\text { Chi } \\
\text { Square } \\
\text { Vale }\end{array}$} & \multirow{3}{*}{ Df } \\
\hline & \multicolumn{2}{|c|}{$\begin{array}{c}\text { No } \\
\text { Erythema }\end{array}$} & \multicolumn{2}{|c|}{ Mild } & \multicolumn{2}{|c|}{ Moderate } & \multicolumn{2}{|c|}{ Severe } & & \\
\hline & f & $\%$ & f & $\%$ & $\mathbf{F}$ & $\%$ & f & $\%$ & & \\
\hline$O_{\mathrm{m} 1 \mathrm{~d} 1}$ & 00 & 0.00 & 05 & 16.6 & 11 & 36.6 & 14 & 46.6 & & \\
\hline$O_{m 2 d 1}$ & 04 & 13.3 & 12 & 40.0 & 12 & 40.0 & 02 & 6.66 & $11.93^{*}$ & 3 \\
\hline$O_{\mathrm{m} 2 \mathrm{~d} 1}$ & 04 & 13.3 & 12 & 40.0 & 12 & 40.0 & 02 & 6.66 & $3.03^{\mathrm{NS}}$ & 3 \\
\hline $\mathbf{O}_{\mathrm{m} 3 \mathrm{~d} 2}$ & 07 & 23.3 & 17 & 56.6 & 05 & 16.6 & 01 & 3.33 & & \\
\hline$O_{m 1 d 1}$ & 00 & 0.00 & 05 & 16.6 & 11 & 36.6 & 14 & 46.6 & $21.80 *$ & 3 \\
\hline $\mathbf{O}_{\mathrm{m} 3 \mathrm{~d} 2}$ & 07 & 23.3 & 17 & 56.6 & 05 & 16.6 & 01 & 3.33 & & \\
\hline $\mathbf{O}_{\mathrm{m} 3 \mathrm{~d} 2}$ & 07 & 23.3 & 17 & 56.6 & 05 & 16.6 & 01 & 3.33 & $10.50 *$ & 3 \\
\hline $\mathbf{O}_{\mathrm{m} 4 \mathrm{~d} 2}$ & 21 & 70.0 & 06 & 20.0 & 03 & 10.0 & 00 & 0.00 & & \\
\hline$O_{m 1 d 1}$ & 00 & 0.0 & 05 & 16.6 & 11 & 36.6 & 14 & 46.6 & $39.66^{*}$ & 3 \\
\hline$O_{\mathrm{m} 4 \mathrm{~d} 2}$ & 21 & 70.0 & 06 & 20.0 & 03 & 10.0 & 00 & 0.00 & 5.00 & $J$ \\
\hline
\end{tabular}

The data presented in above table showed that application of moist heat has significantly reduced the severity of erythema as the computed chi square value between pretest and post test i.e. $\mathrm{O}_{\mathrm{m} 1 \mathrm{~d} 1} \mathrm{Vs}_{\mathrm{s}} \mathrm{O}_{\mathrm{m} 2 \mathrm{~d} 1}(11.93 \mathrm{P}<0.05), \mathrm{O}_{\mathrm{mld} 1} \mathrm{Vs}_{\mathrm{s}} \mathrm{O}_{\mathrm{m} 3 \mathrm{~d} 2}$ $(21.80 \mathrm{P}<0.05), \mathrm{O}_{\mathrm{m} 3 \mathrm{~d} 2} \mathrm{Vs}_{\mathrm{m} 4 \mathrm{~d} 2}(10.50 \mathrm{P}<0.05), \mathrm{O}_{\mathrm{m} 1 \mathrm{~d} 1} \mathrm{Vs}_{\mathrm{m} 4 \mathrm{~d} 2}(39.66 \mathrm{P}<0.05)$ were found to be significant at 0.05 level of significance.

Table-3: Comparison of severity of Induration between pretest and post test observation score among group-1 (Moist Heat Application)

$\mathbf{n}=\mathbf{3 0}$

\begin{tabular}{|c|c|c|c|c|c|c|c|c|c|c|}
\hline \multirow{3}{*}{$\begin{array}{l}\text { Obser } \\
\text { vation }\end{array}$} & \multicolumn{8}{|c|}{ Severity of Induration } & \multirow{3}{*}{$\begin{array}{l}\text { Chi } \\
\text { Square } \\
\text { Vale }\end{array}$} & \multirow{3}{*}{ Df } \\
\hline & \multicolumn{2}{|c|}{$\begin{array}{c}\text { No } \\
\text { Induration }\end{array}$} & \multicolumn{2}{|c|}{ Mild } & \multicolumn{2}{|c|}{ Moderate } & \multicolumn{2}{|c|}{ Severe } & & \\
\hline & f & $\%$ & f & $\%$ & $\mathbf{F}$ & $\%$ & f & $\%$ & & \\
\hline$O_{\mathrm{m} 1 \mathrm{~d} 1}$ & 00 & 0.00 & 03 & 10.0 & 13 & 43.3 & 04 & 13.3 & \multirow{2}{*}{$13.27 *$} & \multirow{2}{*}{3} \\
\hline $\mathbf{O}_{\mathrm{m} 2 \mathrm{~d} 1}$ & 03 & 10.0 & 14 & 46.6 & 10 & 33.3 & 02 & 10.0 & & \\
\hline $\mathbf{O}_{\mathrm{m} 2 \mathrm{~d} 1}$ & 03 & 10.0 & 14 & 46.6 & 10 & 33.3 & 03 & 10.0 & \multirow{2}{*}{$1.17^{\mathrm{NS}}$} & \multirow{2}{*}{3} \\
\hline $\mathbf{O}_{\mathrm{m} 3 \mathrm{~d} 2}$ & 07 & 23.3 & 14 & 46.6 & 07 & 23.3 & 02 & 6.66 & & \\
\hline $\mathbf{O}_{\mathrm{m} 1 \mathrm{~d} 1}$ & 00 & 0.00 & 03 & 10.0 & 13 & 43.3 & 04 & 13.3 & \multirow{2}{*}{$15.19 *$} & \multirow{2}{*}{3} \\
\hline $\mathbf{O}_{\mathrm{m} 3 \mathrm{~d} 2}$ & 07 & 23.3 & 14 & 46.6 & 07 & 23.3 & 02 & 6.66 & & \\
\hline $\mathbf{O}_{\mathrm{m} 3 \mathrm{~d} 2}$ & 07 & 23.3 & 14 & 46.6 & 07 & 23.3 & 02 & 6.66 & \multirow{2}{*}{$9.28 *$} & \multirow{2}{*}{3} \\
\hline $\mathbf{O}_{\mathrm{m} 4 \mathrm{~d} 2}$ & 21 & 66.6 & 05 & 16.6 & 05 & 16.6 & 00 & 0.00 & & \\
\hline
\end{tabular}




\begin{tabular}{|c|c|c|c|c|c|c|c|c|c|c|}
\hline $\begin{array}{l}O_{\mathrm{m} 1 \mathrm{~d} 1} \\
\mathbf{O}_{\mathrm{m} 4 \mathrm{~d} 2}\end{array}$ & $\begin{array}{l}00 \\
20\end{array}$ & $\begin{array}{l}0.00 \\
66.6\end{array}$ & $\begin{array}{l}03 \\
05\end{array}$ & $\begin{array}{l}10.0 \\
16.6\end{array}$ & $\begin{array}{l}13 \\
05\end{array}$ & $\begin{array}{l}43.3 \\
16.6\end{array}$ & $\begin{array}{l}04 \\
04\end{array}$ & $\begin{array}{l}13.3 \\
13.3\end{array}$ & $32.96^{*}$ & 3 \\
\hline
\end{tabular}

The data presented in above table showed that application of moist heat has significantly reduced the severity of induration as the computed chi square value between pre-test and post-test i.e. $\mathrm{O}_{\mathrm{mld} 1} \mathrm{Vs}_{\mathrm{m} 2 \mathrm{~d} 1}(13.27 \mathrm{P}<0.05), \mathrm{O}_{\mathrm{m} 1 \mathrm{~d} 1} \mathrm{Vs}_{\mathrm{m}} \mathrm{O}_{\mathrm{m} 3 \mathrm{~d} 2}$ $(15.19 \mathrm{P}<0.05), \mathrm{O}_{\mathrm{m} 3 \mathrm{~d} 2} \mathrm{Vs}_{\mathrm{m} 4 \mathrm{~d} 2}(9.28 \mathrm{P}<0.05), \mathrm{O}_{\mathrm{m} 1 \mathrm{~d} 1} \mathrm{Vs}_{\mathrm{m} 4 \mathrm{~d} 2}(32.96 \mathrm{P}<0.05)$ were found to be significant at 0.05 level of significance.

Table-4: Comparison of warmth between pre-test and post test observation score among group-1 (Moist Heat Application)

$\mathbf{n}=\mathbf{3 0}$

\begin{tabular}{|c|c|c|c|c|c|c|}
\hline \multirow{3}{*}{$\begin{array}{l}\text { Obser } \\
\text { vation }\end{array}$} & \multicolumn{4}{|c|}{ Warmth } & \multirow{3}{*}{$\begin{array}{l}\text { Chi } \\
\text { Square } \\
\text { Vale }\end{array}$} & \multirow{3}{*}{ Df } \\
\hline & \multicolumn{2}{|c|}{ Present } & \multicolumn{2}{|c|}{ Absent } & & \\
\hline & $\mathbf{f}$ & $\%$ & $\mathbf{F}$ & $\%$ & & \\
\hline$O_{\text {m1d1 }}$ & 30 & 100 & 00 & 0.00 & \multirow{2}{*}{$20 *$} & \multirow{2}{*}{1} \\
\hline$O_{\mathrm{m} 2 \mathrm{~d} 1}$ & 15 & 50.0 & 15 & 50.0 & & \\
\hline$O_{m 2 d 1}$ & 15 & 50.0 & 15 & 50.0 & \multirow{2}{*}{$1.08^{\mathrm{NS}}$} & \multirow{2}{*}{1} \\
\hline $\mathbf{O}_{\mathrm{m} 3 \mathrm{~d} 2}$ & 11 & 36.66 & 19 & 63.33 & & \\
\hline$O_{\mathrm{m} 1 \mathrm{~d} 1}$ & 30 & 100 & 00 & 0.00 & \multirow{2}{*}{$24.95^{*}$} & \multirow{2}{*}{1} \\
\hline $\mathbf{O}_{\mathrm{m} 3 \mathrm{~d} 2}$ & 11 & 36.66 & 19 & 63.33 & & \\
\hline $\mathbf{O}_{\mathrm{m} 3 \mathrm{~d} 2}$ & 11 & 36.66 & 19 & 63.33 & \multirow{2}{*}{$4.35^{*}$} & \multirow{2}{*}{1} \\
\hline$O_{\mathrm{m} 4 \mathrm{~d} 2}$ & 26 & 86.66 & 04 & 13.33 & & \\
\hline$O_{\mathrm{m} 1 \mathrm{~d} 1}$ & 30 & 100 & 00 & 0.00 & \multirow{2}{*}{$45.88^{*}$} & \multirow{2}{*}{1} \\
\hline $\mathrm{O}_{\mathrm{m} 4 \mathrm{~d} 2}$ & 26 & 86.66 & 04 & 13.33 & & \\
\hline
\end{tabular}

The above data showed that application of moist heat has significantly reduced the warmth as the computed chi square value between pre test and post test i.e. $\mathrm{O}_{\text {mld1 }} \mathrm{Vs}$ $\mathrm{O}_{\mathrm{m} 2 \mathrm{~d} 1}(20 \mathrm{P}<0.05), \mathrm{O}_{\mathrm{mld} 1} \mathrm{Vs}_{\mathrm{m} 3 \mathrm{~d} 2}(24.95 \mathrm{P}<0.05), \mathrm{O}_{\mathrm{m} 3 \mathrm{~d} 2} \mathrm{Vs}_{\mathrm{m}} \mathrm{O}_{\mathrm{m} 4 \mathrm{~d} 2}(4.35 \mathrm{P}<0.05)$, $\mathrm{O}_{\mathrm{mld} 1} \mathrm{Vs} \mathrm{O}_{\mathrm{m} 4 \mathrm{~d} 2}(45.88 \mathrm{P}<0.05)$ were found to be significant at 0.05 level of significance.

Table-5: Comparison of Severity of Pain between pre-test and post test observation scores among group-1 (Ice Packs Application)

\begin{tabular}{|c|c|c|c|c|c|c|c|c|c|c|}
\hline \multirow{4}{*}{$\begin{array}{l}\text { Obser } \\
\text { vation }\end{array}$} & & & & & & & & & & 0 \\
\hline & \multicolumn{8}{|c|}{ Severity of Pain } & \multirow{3}{*}{$\begin{array}{l}\text { Chi } \\
\text { Square } \\
\text { Vale }\end{array}$} & \multirow{3}{*}{ Df } \\
\hline & \multicolumn{2}{|c|}{ No Pain } & \multicolumn{2}{|c|}{ Mild } & \multicolumn{2}{|c|}{ Moderate } & \multicolumn{2}{|c|}{ Severe } & & \\
\hline & f & $\%$ & f & $\%$ & $\mathbf{F}$ & $\%$ & f & $\%$ & & \\
\hline $\mathbf{O}_{\text {ild1 }}$ & 00 & 0.00 & 04 & 13.3 & 11 & 36.6 & 15 & 50.0 & \multirow{2}{*}{$18.15^{*}$} & \multirow{2}{*}{3} \\
\hline $\mathbf{O}_{\mathrm{i} 2 \mathrm{~d} 1}$ & 07 & 23.3 & 11 & 36.6 & 11 & 36.6 & 01 & 3.33 & & \\
\hline $\mathbf{O}_{\mathrm{i} 2 \mathrm{~d} 1}$ & 07 & 23.3 & 11 & 36.6 & 11 & 36.6 & 01 & 3.33 & \multirow[t]{2}{*}{$0.28^{\mathrm{NS}}$} & \multirow{2}{*}{3} \\
\hline $\mathbf{O}_{\mathrm{i} 3 \mathrm{~d} 2}$ & 07 & 23.3 & 14 & 46.6 & 09 & 30.0 & 00 & 0.00 & & \\
\hline
\end{tabular}




\begin{tabular}{|c|c|c|c|c|c|c|c|c|c|c|}
\hline $\begin{array}{l}\mathbf{O}_{\mathrm{ild} 1} \\
\mathbf{O}_{\mathrm{i} 3 \mathrm{~d} 2}\end{array}$ & $\begin{array}{l}00 \\
07\end{array}$ & $\begin{array}{l}0.00 \\
23.3\end{array}$ & $\begin{array}{l}04 \\
14\end{array}$ & $\begin{array}{l}13.3 \\
46.6\end{array}$ & $\begin{array}{l}11 \\
09\end{array}$ & $\begin{array}{l}36.6 \\
30.0\end{array}$ & $\begin{array}{l}15 \\
00\end{array}$ & $\begin{array}{l}50.0 \\
0.00\end{array}$ & $22.76^{*}$ & 3 \\
\hline $\begin{array}{l}\mathbf{O}_{\mathrm{i} 3 \mathrm{~d} 2} \\
\mathbf{O}_{\mathrm{i} 4 \mathrm{~d} 2}\end{array}$ & $\begin{array}{l}07 \\
25\end{array}$ & $\begin{array}{l}23.3 \\
83.3\end{array}$ & $\begin{array}{l}14 \\
03\end{array}$ & $\begin{array}{l}46.6 \\
10.0\end{array}$ & $\begin{array}{l}09 \\
02\end{array}$ & $\begin{array}{l}30.0 \\
6.66\end{array}$ & $\begin{array}{l}00 \\
00\end{array}$ & $\begin{array}{l}0.00 \\
0.00\end{array}$ & $21.69 *$ & 3 \\
\hline $\begin{array}{l}\mathbf{O}_{\mathbf{i 1 d} 1} \\
\mathbf{O}_{\mathrm{i} 4 \mathrm{~d} 2}\end{array}$ & $\begin{array}{l}00 \\
25 \\
\end{array}$ & $\begin{array}{r}0.00 \\
83.3 \\
\end{array}$ & $\begin{array}{l}04 \\
03 \\
\end{array}$ & $\begin{array}{l}13.3 \\
10.0 \\
\end{array}$ & $\begin{array}{l}11 \\
02 \\
\end{array}$ & $\begin{array}{r}36.6 \\
6.66 \\
\end{array}$ & $\begin{array}{l}15 \\
00 \\
\end{array}$ & $\begin{array}{l}50.0 \\
0.00 \\
\end{array}$ & $41.03 *$ & 3 \\
\hline
\end{tabular}

*Significant at 0.05 level, NS- Not significant at 0.05 level

The data presented in above table showed that application of ice packs has significantly reduced the intensity of pain as the computed chi square value between pre test and post test i.e. $\mathrm{O}_{\mathrm{i} 1 \mathrm{~d} 1} \mathrm{Vs} \mathrm{O}_{\mathrm{i} 2 \mathrm{~d} 1}(18.15 \mathrm{P}<0.05), \mathrm{O}_{\mathrm{ild} 1} \mathrm{Vs}_{\mathrm{i} 3 \mathrm{~d} 2}(22.76 \mathrm{P}<0.05)$, $\mathrm{O}_{\mathrm{i} 3 \mathrm{~d} 2} \mathrm{Vs} \mathrm{O}_{\mathrm{i} 4 \mathrm{~d} 2}(21.69 \mathrm{P}<0.05), \mathrm{O}_{\mathrm{i} 1 \mathrm{~d} 1} \mathrm{Vs} \mathrm{O}_{\mathrm{i} 4 \mathrm{~d} 2}(41.03 \mathrm{P}<0.05)$ were found to be significant at 0.05 level of significance.

Table-6: Comparison of Severity of Erythema between pre test and post test observation scores among group-1 (Ice Packs Application)

$\mathbf{n}=\mathbf{3 0}$

\begin{tabular}{|c|c|c|c|c|c|c|c|c|c|c|}
\hline \multirow{3}{*}{$\begin{array}{l}\text { Obser } \\
\text { vation }\end{array}$} & \multicolumn{8}{|c|}{ Severity of Erythema } & \multirow{3}{*}{$\begin{array}{l}\text { Chi } \\
\text { Square } \\
\text { Vale }\end{array}$} & \multirow{3}{*}{ Df } \\
\hline & \multicolumn{2}{|c|}{$\begin{array}{c}\text { No } \\
\text { Erythema }\end{array}$} & \multicolumn{2}{|c|}{ Mild } & \multicolumn{2}{|c|}{ Moderate } & \multicolumn{2}{|c|}{ Severe } & & \\
\hline & f & $\%$ & f & $\%$ & $\mathbf{F}$ & $\%$ & $\mathbf{f}$ & $\%$ & & \\
\hline $\mathbf{O}_{\text {ild1 }}$ & 00 & 0.00 & 02 & 6.66 & 10 & 33.3 & 18 & 60.0 & \multirow{2}{*}{$13.27 *$} & \multirow{2}{*}{3} \\
\hline $\mathbf{O}_{\mathrm{i} 2 \mathrm{~d} 1}$ & 02 & 6.66 & 11 & 36.6 & 13 & 43.3 & 04 & 13.3 & & \\
\hline $\mathbf{O}_{\mathrm{i} 2 \mathrm{~d} 1}$ & 02 & 6.66 & 11 & 36.6 & 13 & 43.3 & 04 & 13.3 & \multirow{2}{*}{$0.37^{\mathrm{NS}}$} & \multirow{2}{*}{3} \\
\hline $\mathbf{O}_{\mathrm{i3d} 2}$ & 02 & 6.66 & 12 & 40.0 & 12 & 40.0 & 04 & 13.3 & & \\
\hline $\mathbf{O}_{\text {ild1 }}$ & 00 & 0.00 & 02 & 6.66 & 10 & 33.3 & 18 & 60.0 & \multirow{2}{*}{$14.01 *$} & \multirow{2}{*}{3} \\
\hline $\mathbf{O}_{\mathrm{i} 3 \mathrm{~d} 2}$ & 02 & 6.66 & 12 & 40.0 & 12 & 40.0 & 04 & 13.3 & & \\
\hline $\mathbf{O}_{\mathrm{i3d} 2}$ & 02 & 6.66 & 12 & 40.0 & 12 & 40.0 & 04 & 13.3 & \multirow{2}{*}{$16.87 *$} & \multirow{2}{*}{3} \\
\hline $\mathbf{O}_{\mathrm{i} 4 \mathrm{~d} 2}$ & 17 & 56.6 & 10 & 33.3 & 03 & 10.0 & 00 & 0.00 & & \\
\hline $\mathbf{O}_{\text {ild1 }}$ & 00 & 0.00 & 02 & 6.66 & 10 & 33.3 & 18 & 60.0 & \multirow{2}{*}{$44.10^{*}$} & \multirow{2}{*}{3} \\
\hline $\mathbf{O}_{\mathrm{i4d} 2}$ & 17 & 56.6 & 10 & 33.3 & 03 & 10.0 & 00 & 0.00 & & \\
\hline
\end{tabular}

*Significant at 0.05 level, NS- Not significant at 0.05 level

The data presented in above table showed that application of ice packs has significantly reduced the severity of Erythema as the computed chi square value between pre test and post test i.e. $\mathrm{O}_{\mathrm{ild} 1} \mathrm{Vs}_{\mathrm{i} 2 \mathrm{~d} 1}(13.27 \mathrm{P}<0.05), \mathrm{O}_{\mathrm{ild} 1} \mathrm{Vs}_{\mathrm{i} \text { id2 }}(14.01$ $\mathrm{P}<0.05), \mathrm{O}_{\mathrm{i} 3 \mathrm{~d} 2} \mathrm{Vs}_{\mathrm{i} 4 \mathrm{~d} 2}(16.87 \mathrm{P}<0.05), \mathrm{O}_{\mathrm{ild} 1} \mathrm{Vs}_{\mathrm{i} 4 \mathrm{~d} 2}(44.10 \mathrm{P}<0.05)$ were found to be significant at 0.05 level of significance. 
Table-7: Comparison of Severity of Induration between pre test and post test observation scores among group-1 (Ice Packs Application)

\begin{tabular}{|c|c|c|c|c|c|c|c|c|c|c|}
\hline \multirow{4}{*}{$\begin{array}{l}\text { Obser } \\
\text { vation }\end{array}$} & \multirow{2}{*}{\multicolumn{8}{|c|}{ Severity of Induration }} & \multirow{4}{*}{$\begin{array}{l}\text { Chi } \\
\text { Square } \\
\text { Vale }\end{array}$} & $\mathbf{1}=\mathbf{3 0}$ \\
\hline & & & & & & & & & & \multirow{3}{*}{ df } \\
\hline & \multicolumn{2}{|c|}{$\begin{array}{c}\text { No } \\
\text { Induration } \\
\end{array}$} & \multicolumn{2}{|c|}{ Mild } & \multicolumn{2}{|c|}{ Moderate } & \multicolumn{2}{|c|}{ Severe } & & \\
\hline & f & $\%$ & $\mathbf{f}$ & $\%$ & $\mathbf{F}$ & $\%$ & f & $\%$ & & \\
\hline $\mathbf{O}_{\text {ild1 }}$ & 00 & 0.00 & 00 & 0.00 & 12 & 40.0 & 18 & 60.0 & \multirow{2}{*}{$20.98^{*}$} & \multirow{2}{*}{3} \\
\hline $\mathbf{O}_{\mathrm{i} 2 \mathrm{~d} 1}$ & 02 & 6.66 & 11 & 36.6 & 15 & 50.0 & 02 & 6.66 & & \\
\hline $\mathbf{O}_{\mathrm{i} 2 \mathrm{~d} 1}$ & 02 & 6.66 & 11 & 36.6 & 15 & 50.0 & 02 & 6.66 & \multirow{2}{*}{$1.18^{\mathrm{NS}}$} & \multirow{2}{*}{3} \\
\hline $\mathbf{O}_{\mathrm{i} 3 \mathrm{~d} 2}$ & 02 & 6.66 & 16 & 53.3 & 11 & 36.6 & 01 & 3.33 & & \\
\hline $\mathbf{O}_{\text {ild1 }}$ & 00 & 0.00 & 00 & 0.00 & 12 & 40.0 & 18 & 60.0 & \multirow{2}{*}{$28.03^{*}$} & \multirow{2}{*}{3} \\
\hline $\mathbf{O}_{\mathrm{i} 3 \mathrm{~d} 2}$ & 02 & 6.66 & 16 & 53.3 & 11 & 36.6 & 01 & 3.33 & & \\
\hline $\mathbf{O}_{\mathrm{i} 3 \mathrm{~d} 2}$ & 02 & 6.66 & 16 & 53.3 & 11 & 36.6 & 01 & 3.33 & \multirow{2}{*}{$19.57^{*}$} & \multirow{2}{*}{3} \\
\hline $\mathbf{O}_{\mathrm{i} 4 \mathrm{~d} 2}$ & 18 & 60.0 & 07 & 23.3 & 05 & 16.6 & 00 & 0.00 & & \\
\hline $\mathbf{O}_{\text {ild1 }}$ & 00 & 0.00 & 00 & 0.00 & 12 & 40.0 & 18 & 60.0 & \multirow{2}{*}{$39.37 *$} & \multirow{2}{*}{3} \\
\hline $\mathbf{O}_{\mathrm{i} 4 \mathrm{~d} 2}$ & 18 & 60.0 & 07 & 23.3 & 05 & 16.6 & 00 & 0.00 & & \\
\hline
\end{tabular}

The data presented above table showed that application of ice packs has significantly reduced the severity of Induration as the computed chi square value between pre test and post test i.e. $\mathrm{O}_{\mathrm{i} 1 \mathrm{~d} 1} \mathrm{Vs}_{\mathrm{i} 2 \mathrm{~d} 1}(20.98 \mathrm{P}<0.05), \mathrm{O}_{\mathrm{ild} 1} \mathrm{Vs}_{\mathrm{i} 3 \mathrm{~d} 2}(28.03 \mathrm{P}<0.05), \mathrm{O}_{\mathrm{i} 3 \mathrm{~d} 2}$ Vs $\mathrm{O}_{\mathrm{i} 4 \mathrm{~d} 2}(19.57 \mathrm{P}<0.05), \mathrm{O}_{\mathrm{ild} 1} \mathrm{Vs}_{\mathrm{i} 4 \mathrm{~d} 2}(39.37 \mathrm{P}<0.05)$ were found to be significant at 0.05 level of significance.

Table-8: Comparison of warmth between pre test and post test observation score among group-1 (Ice Packs Application)

\begin{tabular}{|c|c|c|c|c|c|c|}
\hline \multirow{4}{*}{$\begin{array}{l}\text { Obser } \\
\text { vation }\end{array}$} & \multirow{2}{*}{\multicolumn{4}{|c|}{ Warmth }} & \multirow{4}{*}{$\begin{array}{l}\text { Chi } \\
\text { Square } \\
\text { Vale }\end{array}$} & \multirow{4}{*}{$\begin{array}{l}n=30 \\
\text { Df }\end{array}$} \\
\hline & & & & & & \\
\hline & \multirow[b]{2}{*}{ f } & Present & & \multirow{2}{*}{$\begin{array}{c}\text { Absent } \\
\%\end{array}$} & & \\
\hline & & $\%$ & f & & & \\
\hline $\mathbf{O}_{\text {ild1 }}$ & 00 & 0.00 & 30 & 100 & \multirow{2}{*}{$32.30 *$} & \multirow{2}{*}{1} \\
\hline $\mathbf{O}_{\mathrm{i} 2 \mathrm{~d} 1}$ & 21 & 70.0 & 09 & 30.0 & & \\
\hline $\mathbf{O}_{\mathrm{i} 2 \mathrm{~d} 1}$ & 21 & 70.0 & 09 & 30.0 & \multirow{2}{*}{$0.8^{\mathrm{NS}}$} & \multirow{2}{*}{1} \\
\hline $\mathbf{O}_{\mathrm{i} 3 \mathrm{~d} 2}$ & 24 & 80.0 & 06 & 20.0 & & \\
\hline $\mathbf{O}_{\text {ild1 }}$ & 00 & 0.00 & 30 & 100 & \multirow{2}{*}{$36.73 *$} & \multirow{2}{*}{1} \\
\hline $\mathbf{O}_{\mathrm{i} 3 \mathrm{~d} 2}$ & 24 & 80.0 & 06 & 20.0 & & \\
\hline $\mathbf{O}_{\mathrm{i3d} 2}$ & 24 & 80.0 & 06 & 20.0 & \multirow{2}{*}{$2.58^{*}$} & \multirow{2}{*}{1} \\
\hline $\mathbf{O}_{\mathrm{i} 4 \mathrm{~d} 2}$ & 29 & 96.6 & 01 & 3.33 & & \\
\hline $\mathbf{O}_{\text {ild1 }}$ & 00 & 0.00 & 30 & 100 & \multirow{2}{*}{$56.12^{*}$} & \multirow{2}{*}{1} \\
\hline $\mathbf{O}_{\mathrm{i4d} 2}$ & 29 & 96.6 & 01 & 3.33 & & \\
\hline
\end{tabular}


The above data showed that application of ice packs has significantly reduced the warmth as the computed chi square value between pre test and post test i.e. $\mathrm{O}_{\text {ild1 }} \mathrm{Vs}$ $\mathrm{O}_{\mathrm{i} 2 \mathrm{~d} 1}(32.30 \mathrm{P}<0.05), \mathrm{O}_{\mathrm{i} 1 \mathrm{~d} 1} \mathrm{Vs} \mathrm{O}_{\mathrm{i} 3 \mathrm{~d} 2}(36.73 \mathrm{P}<0.05)$ and $\mathrm{O}_{\mathrm{i} 1 \mathrm{~d} 1} \mathrm{Vs}_{\mathrm{i}} \mathrm{O}_{\mathrm{i} \mathrm{d} 2}(56.12 \mathrm{P}<$ 0.05 ) were found to be significant at 0.05 level of significance.

\section{DISCUSSION}

\section{Prevalence of Intravenous Cannulation Induced Thrombophlebitis.}

The study indicated the prevalence of I.V. thrombophlebitis was $54.55 \%$ in the medical and surgical wards unlike the prevalence of peripheral intravenous thrombophlebitis by Esin Cetinkaya Uslusoy et al (2015) and Escola Anna Nery (2014). The results of their study showed that hospitalized patients with intravenous catheter had peripheral venous thrombohlebitis. Similarly the result of study conducted by Wilkinson Yoong Jian Tan et al (2012) showed phlebitis rate 35.2\%.

Compare the effectiveness of moist heat and ice packs application in relieving the I.V. cannulation induced thrombophlebitis.

The study clearly indicated the effectiveness of moist heat and ice packs application in reducing pain, Erythema, warmth and induration. This is supported by study conducted by A Purnungla Aier (2009) that showed that showed that swelling reduced from 1.90 to no swelling and pain reduced from 2.86 to no pain. Another study was conducted by Ishii $\mathbf{K}$ et al (2013) that showed the effectiveness of Ice application at the injection site is safe and effective for reducing pain. In contrast, ice packs application in present study was effective in relieving pain and other symptoms of I.V. thrombophlebitis.

The study indicates the effectiveness of ice packs in relieving pain and swellings that was similar with the study conducted by Navjot Kaur et al (2015). The results of their study showed a higher reduction of pain, discomfort with cold appliction in Infusion phlebitis patients.

\section{CONCLUSION}

The following conclusion can be drawn from the findings of the study: The prevalence of phlebitis was higher in grade-3. The moist heat and ice packs were equally effective in reducing the pain, Erythema, induration and warmth. The moist heat has sustained but ice packs had immediate effects in reducing the signs and symptoms of I.V. cannulation induced thrombophlebitis. There was no association between the level of pain, Erythema, induration and warmth with selected personal variables.

\section{REFERENCES}

1. Larvey I Smith. Peripheral vascular access device: risk prevention and management. British Journal of Nursing 2007 Dec; 22: 1378.

2. Patricia A and Anne G Perry. Basic nursing. $5^{\text {th }}$ ed. London: Elsevier Publications; 2004. p. 367.

3. Bare.G. Brenda and Smeltzer .C. Suzanne. Brunner and Sunddarth's Text book of Medical and Surgical Nursing. Eighth edition. Philadelphia. J.B. Lippincott., 1996.

4. Black .M. Joyce and Jacobs Matassarin Esther. Medical Surgical Nursing Clinical Management for positive outcomes"., Seventh edition., Philadelphia., WB Saunders., 2004. 
5. Maki DG and Marmel LA 1988. Infections due to Infusion Therapy (1988) in Bennett JV, Brachman PS, eds. Hospital Infections. 4th Ed Philadelphia: Lippencot-Raven, 158:81-7.

6. Pettit Janet. Assessment of an Infant with a Peripheral Intravenous device. Journal of National Association of Neonatal Nurses 2003 September; 3(5):230-240.

7. Higa.S.Lisa. IV Catheters. Infection Control Today Magazine, 2009 Jan; 3(6).

8. Harry Owen, Ann Serafim. Peripheral intravenous cannula: advantage and disadvantage. Clinical Demonstrator 2008 Aug; 45(3): 52.

9. Campbell J. Intravenous cannulation: potential complications. Professional Nurse 1997 May; 8: 103. 